\title{
STRATIGRAPHIC ANALYSIS OF THE MARINE CRETACEOUS IN THE EASTERN MARGIN OF POTIGUAR BASIN
}

\author{
JOEL C. DE CASTRO*, MARTHA C. VIVIERS*, and MARÍLIA S.P. REGALI**
}

\begin{abstract}
A detailed sedimentologic-paleoecologic investigation was carried out in the marine Cretaceous section (Albian to Maestrichtian) of the Potiguar Basin. Underlying Alagoas rocks are lacustrine-deltaic sandstones and shales, and minor limestones that represent regional markers; lacustrine fauna is represented by ostracod coquinas, vertebrate remains, stromatolites, and mollusks. The marine section was divided into six major depositional sequences with chronostratigraphic character: shelf clastic and carbonate sequences are separated by regional transgressive events, while the lower boundary of slope sequences is erosional. The sequences and corresponding depositional systems are: VI onlap slope clastics (Ubarana Formation), Maestrichtian-Campanian; V shelf to slope carbonates (Jandaíra Formation), Campanian-Turonian; IV fluvio-deltaic clastics (Açu Formation late Cenomanian; II onlap slope clastics (Ubarana Formation), middle-early Cenomanian; II shelf clastics and carbonates (Açu-Ponta do Mel formations), late Albian; I fluvio-deltaic clastics (Açu Formation), middle-early Albian. The onlapping slope deposits of unit III are located in Ubarana reentrance or canyon, an erosional feature originated at the Albian/Cenomanian boundary and that survived up to the lertiary, when it became the depositional site of thick submarine basalt flows of the Macau Formation (early Miocene-Oligocene). Mapping of these sequences and their systems allows a better understanding of the structural and stratigraphic evolution of the basin.

RESUMO ANÁLISE ESTRATIGRÁFICA DO CRETÁCEO MARINHO DA MARGEM LESTE DA BACIA POTIGUAR. O Cretáceo marinho (Albiano a Maastrichtiano) da margem leste da Bacia Potiguar foi objeto de uma análise estratigráfica detalhada. As rochas representativas deste intervalo se assentam discordantemente sobre depósitos lacustres do Eocretáceo (Alagoas) ou sobre o embasamento. O Cretáceo marinho foi dividiđo em seis seqüências deposicionais, com cárater cronoestratigráfico; seqüências clásticas e carbonáticas de plataforma são separadas entre si por eventos transgressivos regionais, enquanto o limite inferior das seqüências de talude é erosivo. As seqüências e seus correspondentes sistemas deposicionais sâo: VI clásticos de talude em onlap (Formação Ubarana), Maastrichtiano-Campaniano; V carbonatos de plataforma e talude (Formaçăo Jandaíra), Campaniano-Turoniano; IV clásticos flúvio-deltaicos (Formaçāo Açu), Neocenomaniano; III clásticos de talude em onlap (Formaçāo Ubarana), Meso-eocenomaniano; II clásticos e carbonatos de plataforma (formaçōes Açu e Ponta do Mel), Neoalbiano; I clásticos flúvio-deltaicos (Formaçāo Açu), Meso-eoalbiano. Os depósitos de talude em onlap da seqüência III estāo localizados no canyon de Ubarana, uma feiçāo erosiva originada ao final do Albiano e que permaneceu até o Terciário, quando foi preenchida pelos espessos derrames basálticos da Formaçāo Macau (Eomioceno e Oligoceno). O mapeamento dessas seqüências e respectivos sistemas permite compreender a evoluçāo estrutural e estratigráfica da bacia.
\end{abstract}

INTRODUCTION Potiguar Basin is located in the Northeastern Brazilian continental margin; it covers an area of $41,000 \mathrm{~km}^{2}$ both onshore and offshore (Souza 1982, Figure 1). Approximate daily production (September, 1987) is 69,000 bbl of oil and $2,250,000 \mathrm{~m}^{3}$ of gas, mainly from clastic reservoirs of three units: early Cretaceous Pendência and Alagamar formations, and mid-Cretaceous Açu Formation.

The mid and late Cretaceous rocks of the basin were investigated in the present study because of the stratigraphic problems they exhibit: complex relationships between clastics and carbonates, origin and fill of submarine canyons, and framework of marine-dominated deltas. An extensive sedimentologic, paleoecologic, and biostratigraphic (pollens and foraminifers) work was carried out in the eastern portion of the basin (Fig. 1), an area with important oil accumulations and enough well control to allow detailed stratigraphic studies.

As a result, the investigated section was divided into six major depositional sequences, whose characterization and mapping permitted to understand the tectono-sedimentary evolution of this part of the basin.

GEOLOGIC FRAMEWORK The structural framework of Potiguar Basin comprises in the onshore portion three half grabens separated by intrabasinal highs, and a major offshore graben area (also compartimented in half grabens, but not considered here) (Fig. 1). These grabens are related to the early Cretaceous rifting episode of the Brazilian marginal
- basins and they are bounded by stable platforms to the west and southeast.

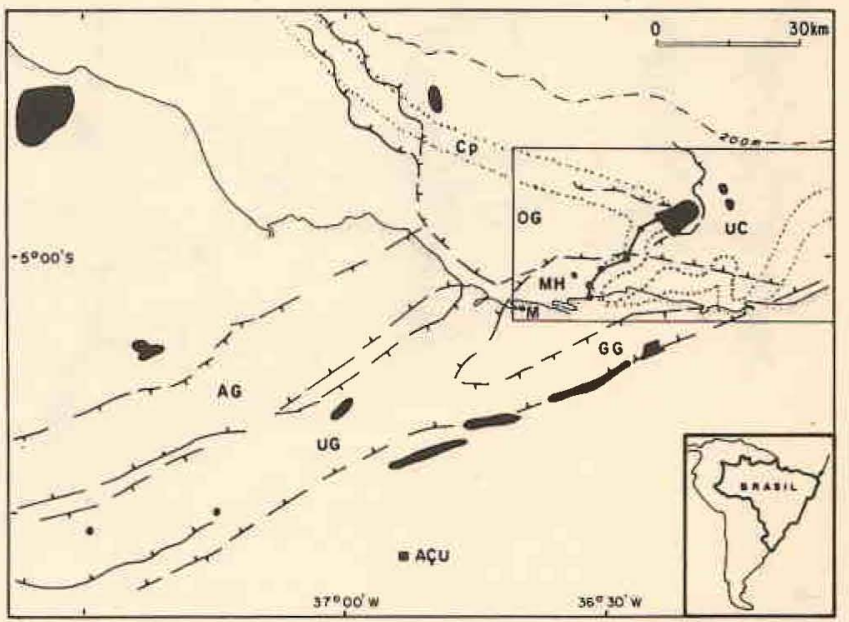

Figure 1 -The structural framework and the oilfields (in black) of Potiguar Basin. Lower Cretaceous grabens (AG, UG, GG, $O G)$ are delineated by major fault trends; Macau High $(M H)$, Ponta do Mel carbonate shelf $\left(C_{P}\right)$, and Ubarana canyon (UC) are indicated, as well as the investigated area and the localization of cross-section of figure $2(M=$ Macau $)$ 
The geologic column of the basin comprises three main intervals separated by regional unconformities (Souza 1982):

a) Neocomian, non-marine, rift deposits of Pendência Formation, which are located in the grabens;

b) Alagoas, alluvial and shallow lacustrine rocks of Alagamar Formation, that blanket the grabens and also the intrabasinal highs;

c) Albian to Recent, with alluvial, transitional, and marine rocks of the miogeoclinal phase of the basin evolution, and that are distributed all over the basin.

The present study focuses on the Cretaceous component of the third interval in the eastern offshore portion of the basin. There, three major tectono-sedimentary provinces can be observed (Fig. 1): the Macau High area, a positive feature always present during the Cretaceous; the carbonate platform belt of the late Albian Ponta do Mel Formation, which becomes reentrant in the Ubarana canyon area; and Ubarana canyon, an erosional feature originated in early Cenomanian that remained as site of deep-water deposition till the Tertiary.

STRATIGRAPHIC ANALYSIS A detailed stratigraphic analysis of the marine Cretaceous section allowed the identification and mapping of six sequences and their corresponding depositional systems. The sequences are: VI onlap slope clastics (Ubarana Formation), Maastrichtian-Campanian;

V shelf to slope carbonates (Jandaíra Formation), Campanian-Turonian;

IV fluvio-deltaic clastics (Açu Formation), late Cenomanian;
III onlap slope clastics (Ubarana Formation), middle-early Cenomanian;

II shelf clastics and carbonates (Açu-Ponta do Mel formations), late Albian;

I fluvio-deltaic clastics (Açu Formation), middle-early Albian.

The clastic-carbonate, sequences I-II, and IV-V, are grouped into two megasequences (Fig. 2). At the boundaries between clastic and carbonatec shelf sequences (that is, between I and II, and between IV and V), it occurs extensive transgressive units composed of shales and/or calcilutites $(m$, on figure 2). The top of the carbonate sequence is also considered as time line. The carbonate shelf system of sequence II does not present a corresponding slope system; this sequence, like the underlying units, is erosionally cut by the succeeding slope system of sequence III. The carbonate sequence $\mathrm{V}$ consists of shelf and slope systems, the latter being fundamental in separating the deep-water clastic sequences III and VI (Fig. 2).

The bounding units of the marine Cretaceous are the Alagoas Alagamar Formation and the Cenozoic fan delta-carbonate shelf-slope systems, with thick submarine volcanics of Macau Formation (Fig. 2).

The Alagamar Formation is subdivided in two units by the important Ponta do Tubarão beds (CPT), a regional marker of marginal lacustrine calcilutites and shales. The upper unit is represented by sandstones and shales formed in lacustrine deltaic settings; the lacustrine basin is suggested by the general early Cretaceous fauna of blue-green algae, pelecypod- and ostracod-coquinas, Estheria, fish remains. However, the upper unit already exhibits some marine

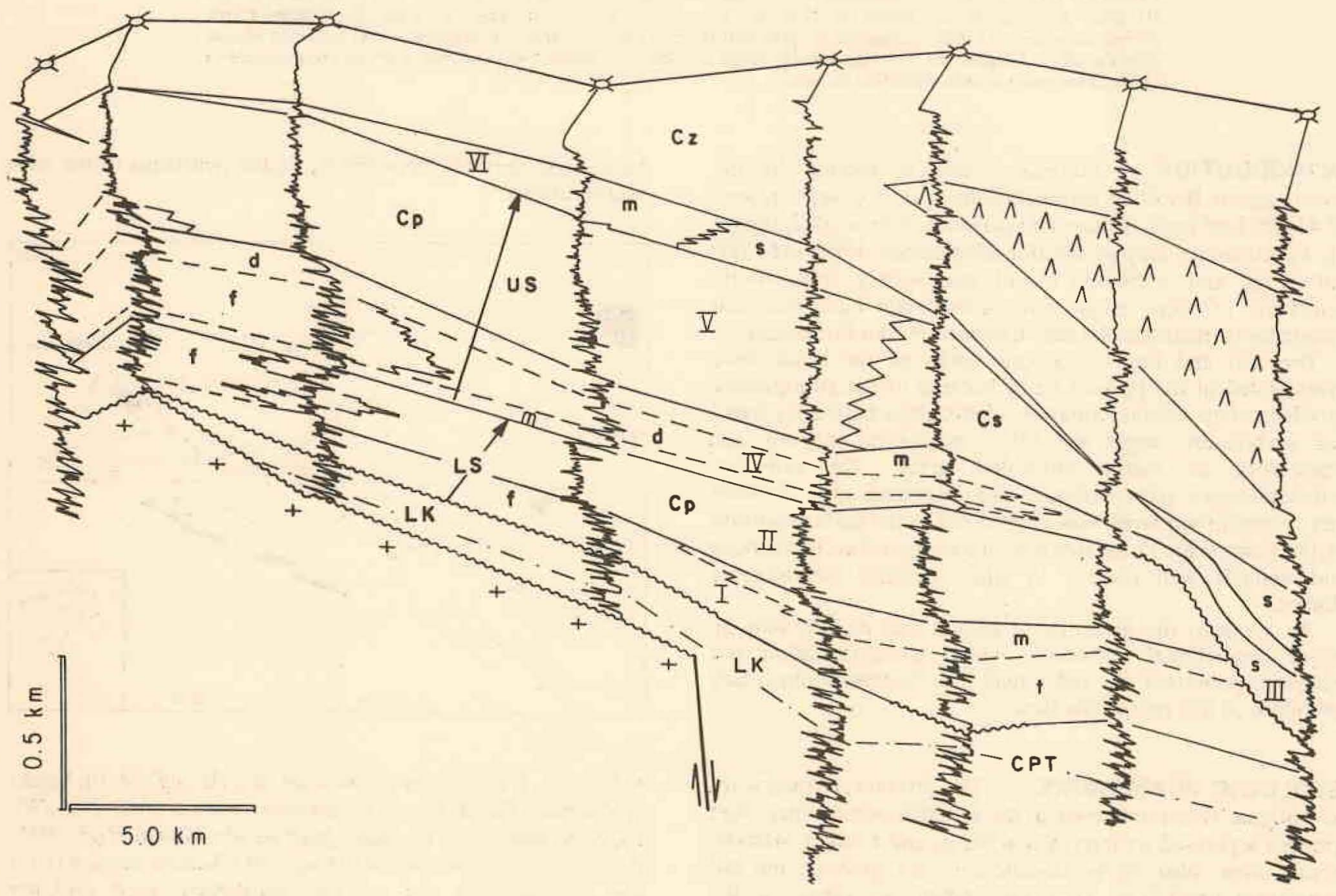

Figure 2 - Geologic framework of Macau-Ubarana area. The six sequences of the marine Cretaceous are indicated by roman numerals and megasequences by LS, US; LK (with CPT marker) and $\mathbf{C z}$ (with volcanic unit) are lower Cretaceous and Cenozoic bounding units. Depositional systems are labeled $\mathbf{f}$ (fluvial, fluvio-estuarine), $\mathbf{d}$ (deltaic), $\mathbf{t}$ (transitional), $\mathbf{m}$ (marine), and $\mathbf{s}$ (slope), and carbonates are $\mathbf{C p}$ (shelf) and $\mathbf{C s}$ (slope). Location of the section in figures 1 and 3 
influence suggested by the occurrence of dynoflagellate and quitinous foraminifers.

The structural map of the top of CPT beds (Fig. 3) displays a northward homoclinal dip, a closer spacing of the contour curves at the faulted northern margin of Macau High, and an inflection of the curves at Ubarana field (see the $-2,400 \mathrm{~m}$ curve, Fig. 3). Also the marker is absent in positive trends within the Macau High.

STRATIGRAPHIC EVOLUTION Sequence I The sequence I records the first phase of sedimentation under real marine influence (early to middle Albian).

The sequence I is formed by three depositional systems (Fig. 2):

a) fluvial, coarse sandstones and conglomerates in Macau High area;

b) coarse to fine sandstones and shales, and rare intercalations of detrital/bioclastic limestones (oncolites, echinoids, mollusks, arenaceous foraminifers etc), representing a transitional association that occurs in Ubarana area;

c) shales and calcilutites with calcispheres and hedbergelliform foraminifers of a marine transgressive origin and that develops on top of the sequence in Ubarana area.

Except for the upper transgressive unit, the first two associations indicated a regressive setting whose distal, argillaceous component was not preserved. Furthermore, the transitional association is composed of regressive, fluvio-deltaic elements and minor transgressive, carbonate elements.

The isopach map of sequence I (Fig. 4-A) shows a thickening in an offshore direction, with an W-E oriented depocenter in Ubarana area; the observed thinning northwards of the depocenter is due to erosional truncation by younger units. Contrasting with the general coarse sedimentation of sequence I there is a localized occurrence of fine grained deposits in an area that later will be occupied by the canyon mouth of sequence III (Fig. 4-A).

Sequence II The sequence II (probably neo-Albian in age) is formed by shelf carbonates of Ponta do Mel Formation and its equivalent coarse clastics of Açu Formation. The carbonate platform constitutes a narrow and elongate belt that runs parallel to the modern shelf, except in Macau-Ubarana area where the belt inflects onshore and becomes reentrant (Fig. 1).

The Ponta do Mel carbonate platform has two distinct provinces: in the belt parallel to the modern shelf edge the limestones are bioclastic to detrital, rarely bioconstructed (corals and encrusting red algae); main bioclasts are red algae, mollusks, green algae, oncolite, benthic foraminifers, etc. (Tibana \& Terra 1981). By the contrary, in Ubarana-Macau reentrance the limestones are mainly oolitic. They are interpreted as an ancient tidal bar belt related to the embayed shape of the platform, similar to modern deep embayments such as Tongue of the Ocean, Bahamas.

Between Ponta do Mel carbonates and Açu fluvio-estuarine clastics (Fig. 4-B) there is a transitional belt characterized by thick, alternate beds of "transgressive", detrital dolosparites and "regressive", coarse to fine sandstones; it is noteworthy in sequence II the absence of fine clastics, attesting the shallowness and high energy conditions of the mixed platform.

The isopach map of sequence II (Fig. 4-B) shows a depocenter elongated $\mathrm{W}-\mathrm{E}$ along the carbonate belt. To the north of the belt the carbonate gets abruptly thin and it is not observed a constructional slope; instead, cores in well from this area only recovered a thin breccia interval composed of limestone fragments set up in an argillaceous matrix, suggesting a starved, destructive shelf margin-type. Also at

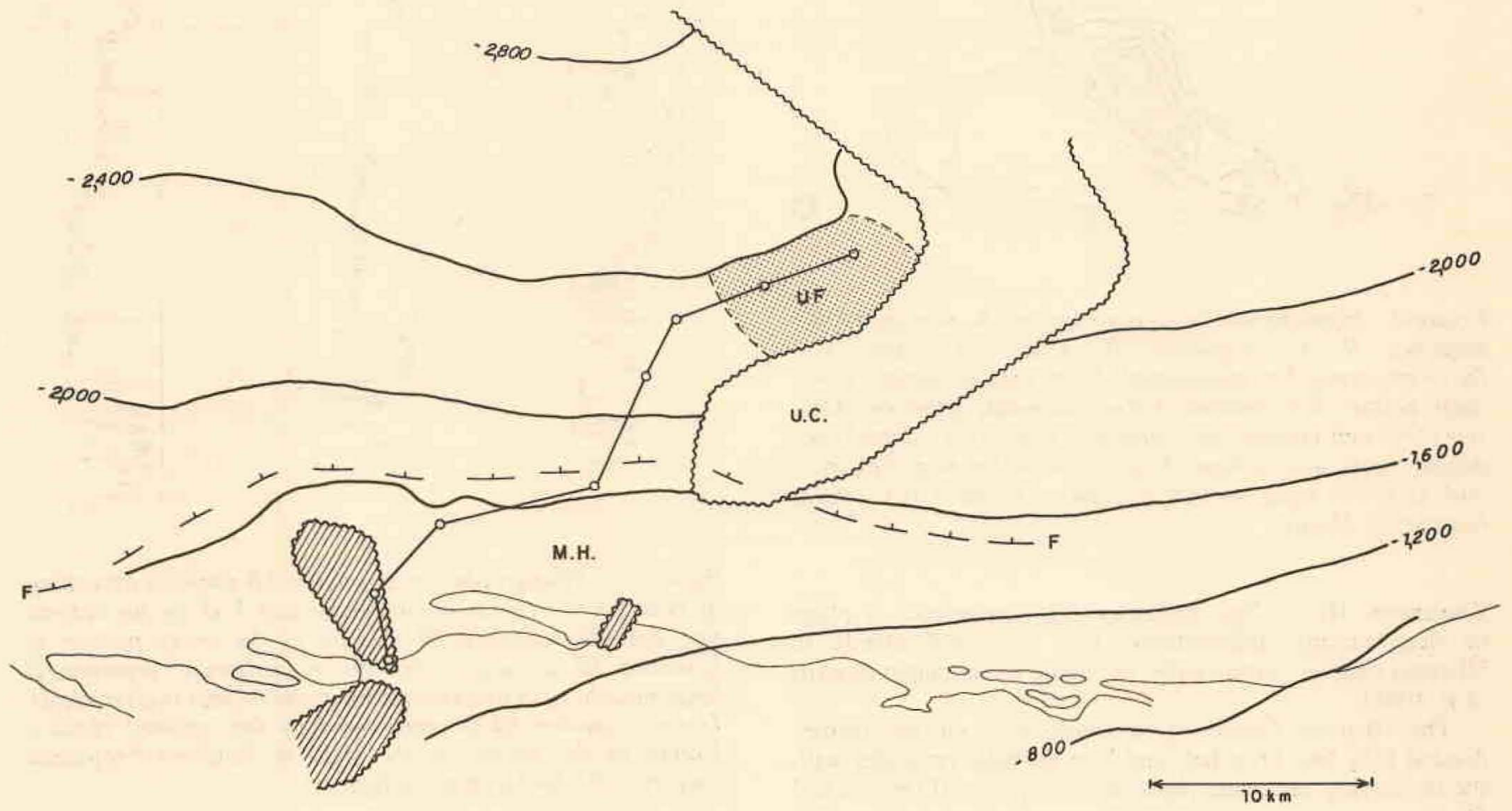

Figure 3 - Simplified structural map of top of CPT marker. Notice general homoclinal dip towards north and inflection of $-2,400 \mathrm{~m}$ curve at Ubarana field (UF) structure. Major fault $(F)$ delimits Macau High area $(M H)$ to the south with secondary highs where CPT is absent by post-Alagoas erosion (hachured areas); CPT is also eroded in Ubarana canyon (UC). Location of cross-section of figure 2 is indicated 
Ubarana-Macau reentrance the carbonate shelf margin has been eroded by the canyon which developed in sequence III (Figs. 5 and 6).
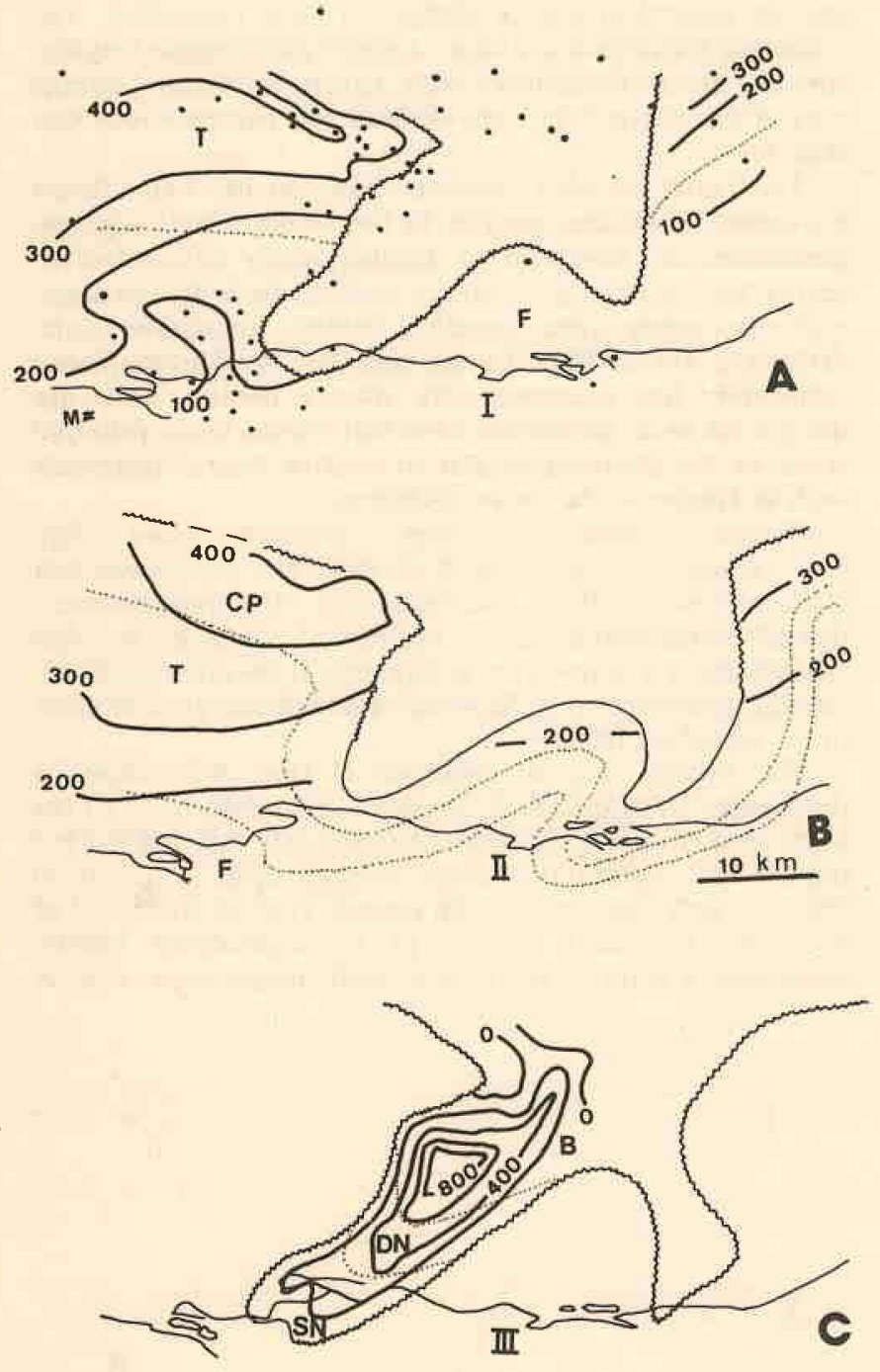

Figure 4 - Isopachs and facies associations: A. sequence I; B. sequence II; C. sequence III. Code for letters: $F=$ fluvio-estuarine; $T=$ transitional; $S N=$ shallow neritic; $D N=$ deep neritic; $B=$ bathyal; $C P=$ carbonate platform. Dots represent well control (only shown in figure 6-A); dotted lines delimit facies associations. Area shown in the maps (figure 5 and 8 ) is the same as that of figures 3 and 4 (Cf. littoral contour; M. Macau)

Sequence III The sequence III corresponds a phase of deep marine sedimentation that developed mainly in Ubarana canyon, during early to middle Cenomanian (Castro et al. 1986).

The Ubarana canyon is an erosional, reentrant feature divided into two branches, and that partially coincides with the underlying carbonate platform of sequence II (Figs. 1 and 5).

A geologic cross-section in the western branch (Fig. 6) shows that erosion exposes progressively subcrops of older units towards the axis of the canyon. A structural map of this erosional surface (that is, the limit between sequences II and

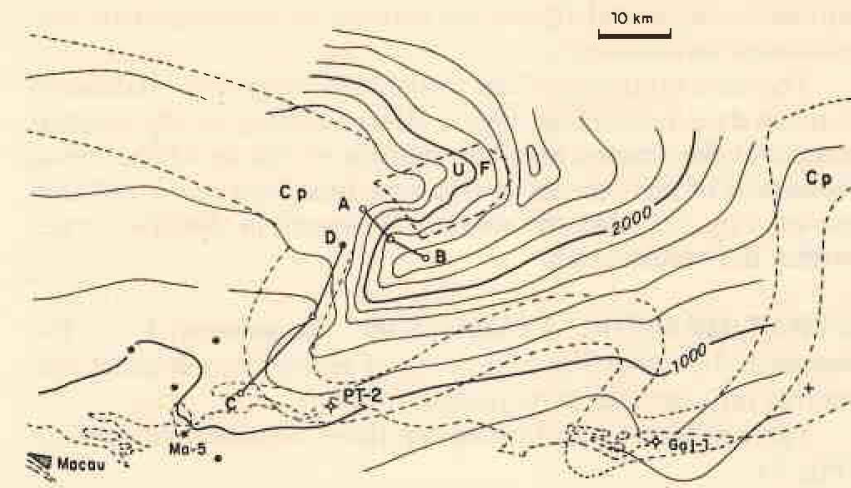

Figure 5 - Combined structural map of the top of carbonate sequence II and base of canyon sequence III. Notice contour of carbonate shelf sequence II $(C p)$ and localization of Ubarana field $(U F)$ in the $N W$ margin of the canyon

III) suggests a maximum topographic relief of $900 \mathrm{~m}$ and a declivity of $11^{\circ}$ for the canyon; the same declivity can be calculated for the frontal slope northwards of the Ponta do Mel carbonate shelf (Fig. 5).

The origin of the canyon can be related to three factors: a) an accentuated original relief on the frontal and lateral margins of the underlying carbonate shelf;

b) the reentrant nature of the underlying carbonate shelf that would approximate the future margin (inherited from the underlying carbonates) and the fluvial clastic sources;

c) a possible sea level drop (after the highstand deposition of sequence II) that could be tied to a global event at $97 \mathrm{Ma}$ (Vail et al. 1977).

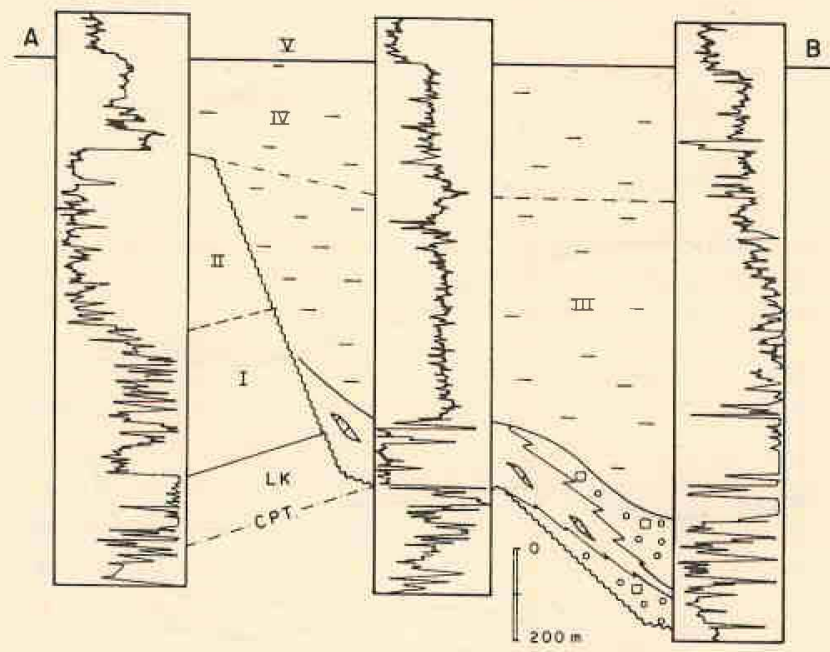

Figure 6 - Stratigraphic cross section $A B$ showing truncation of both lower Cretaceous and sequences $I, I I$, by the canyon that delimits sequence III. Notice in the lower portion of sequence III a major olistolith of carbonate sequence II (intermediate well) and coarse detritus/turbidites (well at right). Upper sequence III is represented by fine grained clastics. Datum of the section is the base of Jandaira Formation (sequence V); for location see figure 5

The canyon fill episode of sequence III occurred in two distinct phases (Fig. 6): the initial one, marked by coarse facies development, and the final one, dominated by fine 
clastics. The initial deposits include immense carbonate olistoliths that were eroded from the adjacent carbonate platform, and carbonate debris flows; conglomerates/sandstones with Bouma sequence $\mathrm{T}_{\mathrm{AB}}$; and shales bearing a bathyal assemblage of Bathysiphon and Zoophycus. The isopach map of sequence III follows the general shape of the structural contours (Figs. 4 and 5). The canyon fill represents a transgressive onlap that reaches the canyon mouths at the end of sequence III deposition, and that is followed by the regressive, deltaic sedimentation of sequence IV. Paleoecologic analysis identified three associations: bathyal (already commented), deep neritic (with planktonic foraminifers) and shallow neritic (poor fauna).

Sequence IV The sequence IV corresponds to the neo-Cenomanian deposition of fluvio-deltaic clastics after the deepwater phase of sequence III (Fig. 6).

The sequence IV comprises two characteristic and major intervals (Fig. 7): a lower, regressive one, with fluvio-estuarine clastics grading to shallow marine fine clastics, and an upper, transgressive one, with deep neritic shales grading onshore to shallow neritic/transitional fine sandstones, shales, and detrital/bioclastic limestones.

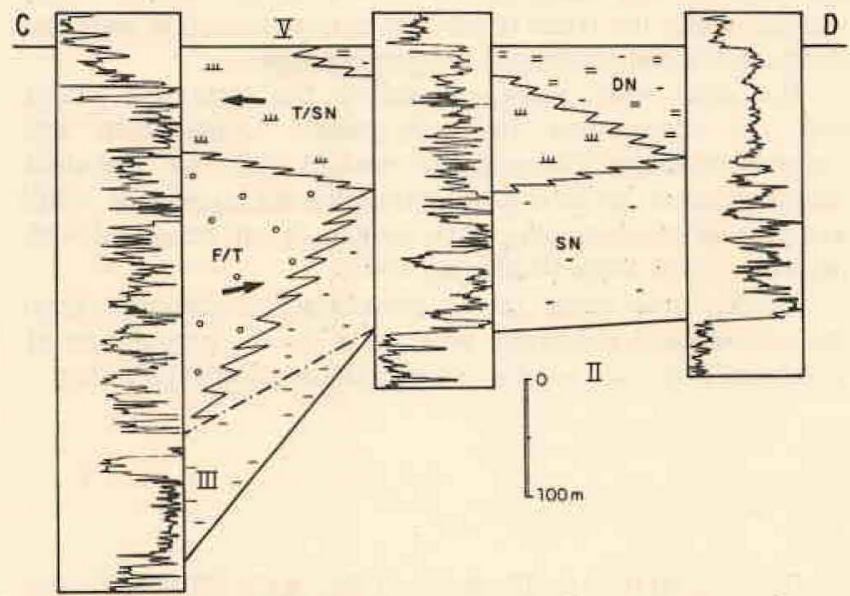

Figure 7 - Stratigraphic cross-section $C D$ showing facies association and framework of sequence $I V$ (after transgressive sequence III), composed of a regressive episode with coarse clastics of fluvio-estuarine origin $(F / T)$ grading to shallow marine, finer-grained clastics (SN), and a transgressive episode composed of deep neritic shales (DN) that grade to shallow marine transitional sediments ( $C F$, figure 8-A). Datum is base of Jandatra Formation (sequence V), and location is shown in figure 5

A closer look at the lower interval allows to identify four facies associations that can be ascribed to a fluvial- and tide-dominated delta. These associations are (Figs. 7 and 8-A):

a) fluvio-estuarine, represented by fining-upward sequences of coarse, cross-bedded sandstones to fine/medium, argillaceous and bioturbated sandstones;

b) transitional/paralic, an association of the previous facies plus bioclastic/detrital calcarenites, dolosparites, and shales with arenaceous foraminifers and ostracods;

c) shallow neritic, or delta front/prodelta, marked by thick ( 6 to $8 \mathrm{~m}$ ) intercalations of shales, with planktonic and benthonic fauna, and sandstones. The sandstones belong to two types, coarse-grained and cross-bedded with shale drapes and clasts (tidal bars?), and fine/medium grained with Bouma sequence
$\mathrm{T}_{\mathrm{AB}}$ (delta front turbidites);

d) deep neritic, or prodelta/marine shales with a rich fauna of hedbergelliform planktonic foraminifers.

The upper transgressive interval has been interpreted as a wave-and tide-dominated delta, similar to the modern deltaic sedimentation of Açu River in the mesotidal Northeastern Brazilian coast (Castro et al. 1982).

An important point in both models is the vertical facies variation, as exemplified by the shallow neritic association: the contacts between the regressive sandstones and the transgressive shales are abrupt, and could be related to small sea level fluctuations, i.e. negative oscillations would favor the access of coarse clastics to the shelf, while positive fluctuations would favor the transgressive shales to be deposited.

The isopach map of sequence IV shows a thinning towards offshore and a depocenter localized in a position formerly occupied by the canyon mouth of sequence III (compare figure 8-A and 4-C); this depocenter coincides with the maximum development of fluvio-estuarine facies from the lower interval of sequence IV (Fig. 7).
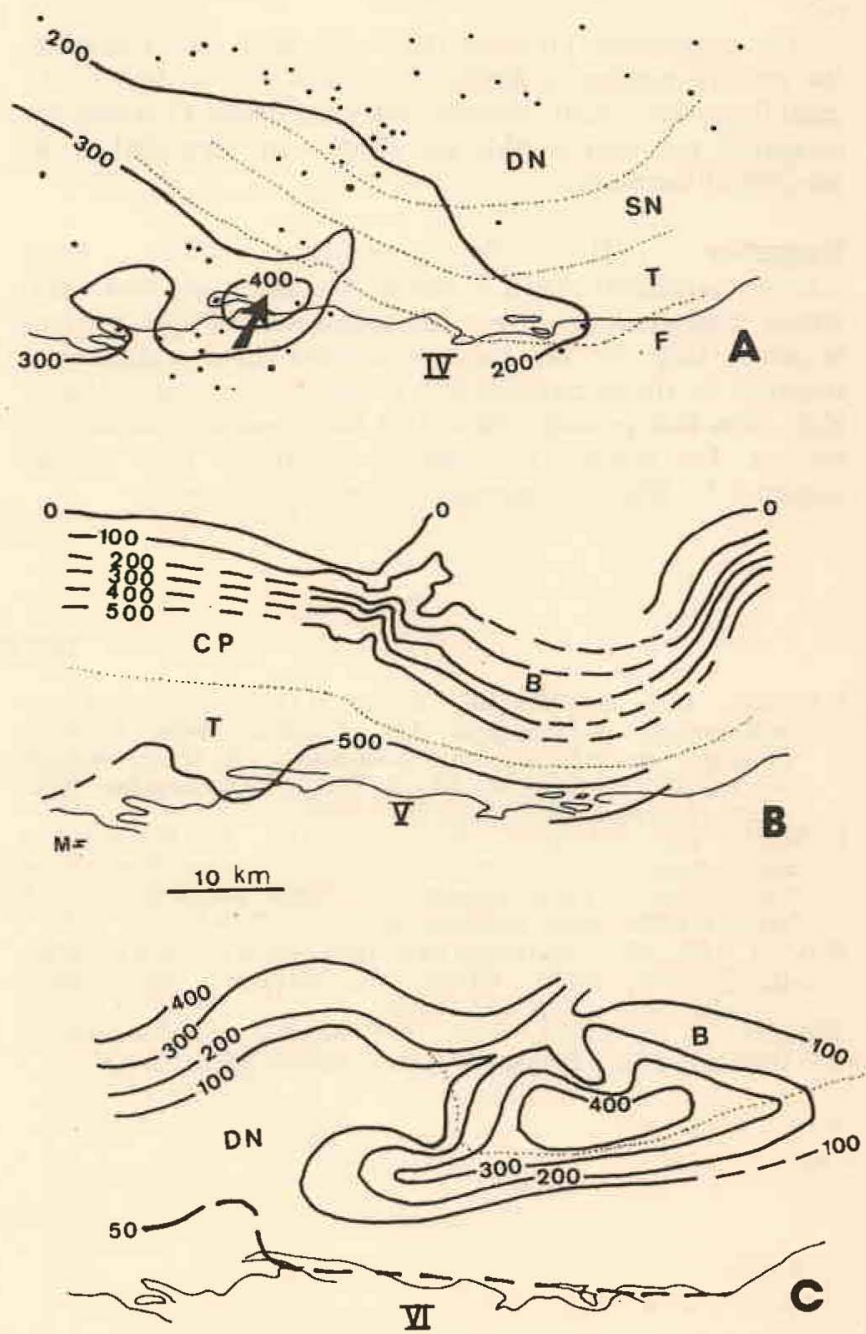

Figure 8 - Isopachs and facies associations: A. sequence $I V$; B. sequence V; C. sequence VI. Key for abbreviations, see figure 4

Sequence V The sequence V corresponds to the shelf and slope carbonate sedimentation of Jandaíra Formation (Turonian to Campanian). The base of the sequence represents a major transgressive event that took place during the 
eo-Turonian: their limestones and shales show a gradation from lagoonal/shallow neritic in Macau High area to deep neritic/bathyal in Ubarana area. These latter environments are represented by a fauna of hedbergelliform planktonic foraminifers and absence of benthic forms (Zone Whiteinella brittonensis, Viviers \& Regali 1987), attesting an anaerobic bottom that can be correlated with an anoxic event of same age in the Atlantic region.

The isopach map of sequence V, together with the paleoenvironmental map of Santonian (Fig. 8-B; see also figure 2), demonstrates an almost complete fill of Ubarana canyon area at that time. The map reveals a depocenter trending E-W, with thickness over $500 \mathrm{~m}$, located over Macau High and dominated by two facies associations: a shallow neritic carbonate platform (fauna of Inoceramus, ostracodes and micromollusks) that becomes enriched in terrigenous from a lagoonal setting in a landwards direction. To the north there is a gradual thinning of the sequence and the predominance of outer shelf-slope conditions as demonstrated by the carbonate microfacies of peloidal/bioclastic/detrital calcissiltites with planktonic and benthonic foraminifers, ostracods, echinoids, vegetal remains, etc.

The remarkable presence of clastics near shelf margin in the eastern portion of Potiguar basin is not verified in the central portion (along onshore grabens, figure 1) where the carbonate platform is wide and clastics are restricted to the margins of the basin.

Sequence VI The sequence VI from Campanian/Maestrichtian is formed by shales and marls that onlaps transgressively over the limestones of the previous sequence (Fig. 2); the contact between these sequences is recorded by the occurrence of a radioactive marker in Macau High area that probably reflects a hardground or condensed section. The isopach and paleoenvironmental map for the sequence VI (Fig. 8-C) reveals two main provinces: a) a bathyal one with two depocenters (over $400 \mathrm{~m}$ ), one in the position of the former Ubarana canyon, and the other towards northwest. These two areas are separated by a sill zone trending ENE-WSW where the Agulha field is located, with oil production from turbidites of sequence VI;

b) a deep to intermediate neritic zone, marked by a gradual thinning and final wedging of the sequence a few kilometers south of the $50 \mathrm{~m}$ isopach. The deep neritic fauna is dominated by a diversified assemblage of planktonic foraminifers (Rugoglobigerina, Globotruncana, Heterohelicidae, etc), while the intermediate neritic presents specialized faunas such as the Campanian Buliminidae, plus cephalopods, other mollusks, etc.

CONCLUSIONS In the eastern portion of Potiguar Basin the marine Cretaceous sedimentary rocks overlie unconformably the basement or early Cretaceous, non marine rocks.

This stratigraphic analysis conducted to the characterization of six depositional sequences, with approximate chrono-stratigraphic significance, and that can be conveniently grouped in megasequences. Two shelf megasequences are dominated by fluvio-deltaic clastics (I, IV) followed by fluvio-estuarine clastics and shelf carbonates (II, V); the shelf carbonate systems behave differently, the early one (late Albian) being narrow and with an erosional shelf margin, white the latter (Turonian to Campanian) is wide and merging in a constructional, prograding slope.

The deep-water sequences follow the carbonate phases and are represented by early-middle Cenomanian and Campanian-Maestrichtian clastic wedges (III, IV). The shelf megasequences are correlated with sea level highstands, while the base of the onlapping slope sequences can be linked with major sea level drops (Vail et al. 1977).

Besides their value in the environmental reconstruction, the depositional sequences were used for the preparation of structural maps that are fundamental tools in oil exploration.

\section{REFERENCES}

CASTRO, J.C.; BARROCAS, S.L.S.; LIMA, H.P. 1982. A sedimentaçâo da Formaçâo Açu, Cretáceo Médio da Bacia Potiguar, e um análogo recente: o estuário do rio Açu na regiảo de Macau, RN. In: CONGR. BRAS. GEOL., 32, Salvador, 1982. Anais... Salvador, SBG. v.5, p. 2417-2423.

CASTRO, J.C.; VIVIERS, M.C.; REGALI, M.S.P. 1986. A sedimentação em "canyons" submarinos e deltas marinhos no Cenomaniano da Bacia Potiguar. In: CONGR. BRAS. GEOL., 34, Goiânia, 1986. Anais... Goiânia, SBG. v.1, p. 298-307.

SOUZA, S.M. 1982. Atualizaçāo da litoestratigrafia da Bacia Potiguar. In: CONGR. BRAS. GEOL., 32, Salvador, 1982. Anais... Salvador, SBG. v. 5, p. 2392-2406.

TIBANA, P. \& TERRA, G.J.S. 1981. Seqüências carbonáticas do Cretáceo na Bacia Potiguar. B. Téc. Petrobrás, 24(3):174-183.
VAIL, P.R.; MITCHUM JR., R.M.; TODD, R.G.; WIDMIER, J.M. THOMPSON III, S.; SANGREE, J.B.; BUBB, J.N.; HATLELID, W.G. 1977. Seismic stratigraphy and global changes of sea level. In: PAYTON, C.E. ed. Seismic stratigraphy. Tulsa, AAPG.p. 49-212.

VIVIERS, M.C. \& REGALI, M.S.P. 1987. Estudo paleoambiental preliminar do Cretáceo da Bacia Potiguar. Rev. Bras. Geoc., 17(2): $123-130$.
MANUSCRTTO 509

Recebido em 02 de dezembro de 1987 Revisão aceita em 05 de abril de 1988 